\title{
PkM Peningkatan Kecerdasan Emosi dan Kemampuan Berbahasa Inggris melalui Kegiatan Mendongeng pada Siswa Sekolah Dasar di Kota Tegal
}

\author{
Endang Sulistianingsih ${ }^{\# 1}$, Sanday Jamaludin ${ }^{* 2}$, Sumartono*3 ${ }^{* 3}$ Deddy Prihadi ${ }^{* 4}$ \\ ${ }^{\# 1}$ Program Studi Pendidikan Bahasa Inggris, Universitas Pancasakti Tegal \\ Jalan Halmahera Km 1 Tegal \\ lendang.sulistiaegmail.com \\ *2 Program Studi Pendidikan Bahasa Inggris, Universitas Pancasakti Tegal \\ Jalan Halmahera Km 1 Tegal \\ ${ }^{2}$ sandayjamaludinegmail.com \\ *3 Program Studi Pendidikan Bahasa Inggris, Universitas Pancasakti Tegal \\ Jalan Halmahera Km 1 Tegal \\ $3_{\text {smart.onpbiegmail.com }}$ \\ ${ }^{* 4}$ Program Studi Manajemen, Universitas Pancasakti Tegal \\ Jalan Halmahera Km 1 Tegal \\ ${ }^{4}$ deddy prihadieyahoo.com
}

ABSTRAK

Kegiatan Program Kemitraan Masyarakat (PKM) ini bertujuan untuk meningkatkan kecerdasan emosi anak sekaligus kemampuan berbahasa Inggris. Hal ini dilakukan melalui pelaksanaan kegiatan mendongeng dan dongeng tersebut disampaikan dalam bahasa Inggris. Penyampaian dongeng dalam bahasa Inggris adalah atas permintaan mitra, mengingat dalam kurikulum 2013 tidak ada mata pelajaran bahasa Inggris. Padahal bahasa Inggris sangat dibutuhkan dalam era globalisasi. Orang tua murid khususnya sekolah-sekolah swasta sangat menghendaki agar mata pelajaran bahasa Inggris tetap diberikan kepada anak-anak mereka meskipun hanya melalui ekstra kurikuler atau jam tambahan di sekolah. Target yang ingin dicapai adalah adanya peningkatan kecerdasan emosi anak dan kemampuan berbahasa Inggris pada siswa Sekolah Dasar. Mitra PKM yaitu SDIT Usamah dan SD Ihsaniyah Gajahmada. Serta pelatihan yang diberikan kepada guru-guru untuk meningkatkan kompetensi digital literacy nya. Dalam hal ini guru diharapkan dapat meningkatkan kualitas mengajarnya. Dari sebelum pelatihan kebanyakan para guru hanya memanfaatkan papan tulis dan spidol untuk mengajar, dengan adanya pelatihan ini guru diharapkan mampu membuat media pengajaran menarik yang berbasis digital. Target yang sudah dicapai adalah adanya kegiatan mendongeng menggunakan dongeng digital yang berbahasa Inggris. Serta pelatihan membuat media pembelajaran berbasis digital yang diikuti oleh sekitar 60 guru yang berasal dari SDIT Usamah dan SD Ihsaniyah Gajahmada. Hasil yang sudah dicapai adalah adanya peningkatan kecerdasan emosi anak dan kemampuan berbahasa Inggris siswa pada sekolah mitra dan para guru berhasil membuat video pembelajaran.

Kata kunci : dongeng digital, kecerdasan emosi, kemampuan berbahsa Inggris

\section{Pendahuluan}

Berdasarkan observasi dan wawancara dengan beberapa guru di SDIT Usamah dan SD Ihsaniyah Gajahmada pada bulan Juni 2017 diperoleh informasi bahwa SDIT Usamah dan SD Ihsaniyah Gajahmada merupakan Sekolah Dasar Swasta yang sudah menerapkan kurikulum 13. Kedua sekolah termasuk SD unggulan di
Kota Tegal. Permasalahan yang dihadapi oleh mitra adalah sekolah mendapatkan banyak keluhan dari orang tua murid bahwa anak mereka lebih senang memegang gadget daripada belajar. Anak-anak emosi nya tidak stabil sering meledak-ledak sulit dikontrol. Motivasi belajar anak rendah. Anak-anak lebih senang menonton TV dan bermain game daripada belajar. Orang tua murid juga mengeluh anak-anak mereka mudah marah dan kurang berempati. Dan orang tua murid bingung menghadapi 
permasalahan tersebut dan menyerahkan permasalahan tersebut kepada sekolah. Orang tua murid berharap kepada sekolah untuk memberikan solusi atas permasalahan mereka. Mereka berharap sekolah dapat membentuk kecerdasan emosi anak.

Permasalahan lain yang dihadapi oleh mitra adalah bahasa Inggris sudah dihapus di kurikulum 13, padahal sebagian besar orang tua murid menghendaki agar anakanak mereka pandai berbahasa Inggris. Hal ini disebabkan karena bahasa Inggris sangat dibutuhkan dalam era globalisasi. Orang tua merasa anaknya akan lebih siap bersaing (lebih kompeten) jika anak mereka bisa mahir berbahasa Inggris sejak dini. Mengacu kepada butir analisis situasi maka permasalahan mitra yaitu; a) Motivasi belajar siswa rendah, b) Siswa lebih senang bermain gadget daripada membaca buku pelajaran, c) Siswa kurang mempunyai rasa empati, d) Emosi siswa tidak stabil, d) Siswa mudah marah dan sulit mengendalikan emosi, e) Mata pelajaran bahasa Inggris ditiadakan dalam kurikulum 13. Berdasarkan permasalahan mitra PKM maka persoalan prioritas yang disepakati untuk diselesaikan selama program PKM adalah sebagai berikut "Peningkatan Kecerdasan Emosi Dan Kemampuan Berbahasa Inggris Melalui Kegiatan Mendongeng Pada Siswa Sekolah Dasar Di Kota Tegal”.

\section{TARGET DAN LUARAN YANG DICAPAI}

Solusi yang ditawarkan untuk menyelesaikan permasalahan yang dihadapi mitra PKM adalah; a) Pembinaan Guru bahasa Inggris yang diharapkan dapat mengatasi permasalahan pembelajaran bahasa Inggris dan mampu menjadi wahana dalam memfasilitasi peningkatan kecerdasan emosi siswa, b) Menambah pengetahuan para guru tentang penerapan IPTEK yaitu melalui pemanfaatan dongeng digital untuk meningkatkan kecerdasan emosi anak dan kemampuan berbahasa Inggris siswa. Hal ini dilakukan melalui pelaksanaan sosialisasi dan bimtek.

Berdasarkan solusi yang ditawarkan tersebut maka target luaran dalam PKM ini adalah sebagai berikut; a) Adanya peningkatan kecerdasan emosi siswa melalui kegiatan mendongeng. Karena berdasarkan hasil penelitian yang telah dilakukan oleh (Shapiro, 1998; Isbell et al., 2004; Staden and Watson, 2007; Sulistianingsih, 2017) dongeng mempunyai kemampuan untuk menciptakan lingkungan belajar yang benar untuk siswa anak usia dini. Selain itu, metode dongeng dapat dijadikan sebagai media membentuk kepribadian dan moralitas anak., b) Adanya peningkatan kemampuan berbahasa Inggris siswa Sekolah Dasar khususnya peningkatan vocabulary.

\section{METODE PELAKSANAAN}

Metode pelaksanaan kegiatan dalam Program Kemitraan Masyarakat (PKM) Peningkatan Kecerdasan Emosi Dan Kemampuan Berbahasa Inggris Melalui Kegiatan Mendongeng Pada Siswa Sekolah Dasar di Kota
Tegal terdiri dari empat tahapan, yaitu perencanaan, tindakan, observasi dan evaluasi, dan refleksi. Kegiatankegiatan atau aktivitas-aktivitas dari masing-masing tahapan adalah sebagai berikut:

\section{A. Perencanaan}

Kegiatan perencanaan berlangsung selama satu bulan. Kegiatan - kegiatan yang dilakukan pada tahap perencanaan adalah sebagai berikut.

1) Koordinasi antara Tim Pelaksana PKM dengan LPPM Universitas Pancasakti Tegal: Pelaksanaan kegiatan pada tahap ini dimulai dengan mengundang tim pelaksana untuk mengadakan pertemuan persiapan pelaksanaan dengan melibatkan LPPM Universitas Pancasakti Tegal, Tim pelaksana kemudian diberikan pembekalan mengenai maksud, tujuan, rancangan mekanisme Program Kemitraan Masyarakat (PKM), dan beberapa hal teknis berkaitan dengan metode/teknik pelaksanaan.

2) Sosialisasi Program Kemitraan Masyarakat (PKM) pada sekolah mitra (khalayak sasaran): Sosialisasi dilakukan dalam bentuk koordinasi antara tim pelaksana dengan sekolah mitra.

3) Penyusunan program pelatihan mendongeng menggunakan dongeng digital: Berdasarkan hasil identifikasi, hasil analisis permasalahan yang ada, hasil kebutuhan, dan hasil analisis potensi sekolah, selanjutnya disusun program pelatihan.

\section{B. Tindakan}

Tindakan dalam kegiatan ini berupa implementasi program, yang direncanakan berlangsung selama 2 bulan. Kegiatan-kegiatan yang dilakukan dalam implementasi program adalah sebagai berikut:

- Meningkatkan pengetahuan dan keterampilan para guru tentang pembuatan media pembelajaran dengan pendekatan IPTEK terapan.

- Mendemonstrasikan teknologi pembuatan media pembelajaran khususnya bahasa Inggris menggunakan teknologi digital.

- Pembimbingan dan praktek pembuatan media pembelajaran bahasa Inggris berbasis digital

- Pembimbingan cara penggunaan media pembelajaran berbasis dongeng digital dalam pembelajaran bahasa Inggris di kelas. Sebelum pelaksanaan pelatihan dilakukan koordinasi pelaksanaan dengan Kepala SDIT Usamah dan SD Ihsaniyah Gajahmada

- Memutar dongeng digital hasil karya pengusul pada siswa di Sekolah mitra yaitu SDIT Usamah dan SD Ihsaniyah Gajahmada 


\section{Observasi dan Evaluasi}

Observasi dan evaluasi berlangsung dalam kurun waktu 3 bulan. Observasi dilakukan terhadap peningkatan kecerdasan emosi dan juga peningkatan kemampuan berbahasa Inggris siswa pada sekolah mitra. Instrument yang digunakan dalam tahap ini berupa angket yang diadopsi dari teori yang dicetuskan oleh (Goleman, 2005) tentang kecerdasan emosi. Untuk mengetahui kemampuan berbahasa Inggris siswa pada sekolah mitra, pengusul memberikan tes dasar tertulis bahasa Inggris. Pengusul memberikan pre-test dan post-test untuk mengetahui peningkatan kecerdasan emosi dan kemampuan berbahasa Inggris siswa pada sekolah mitra. Hasil angket dikalkulasi menggunakan program SPSS dan analisis uji beda dua rata-rata atau t-test digunakan untuk mengevaluasi peningkatan kecerdasan emosi dan kemampuan berbahasa Inggris siswa pada sekolah mitra.

\section{Refleksi}

Refleksi dilakukan terhadap kegiatan yang telah dilaksanakan. Hal ini dilakukan untuk mengetahui kekurangan-kekurangan atau keberhasilan terhadap kegiatan-kegiatan yang telah dilakukan untuk menetapkan rekomendasi terhadap keberlangsungan atau pengembangan kegiatan-kegiatan berikutnya.

\section{HASIL DAN PEMBAHASAN}

Hasil pelaksanaan kegiatan PKM "Peningkatan Kecerdasan Emosi Dan Kemampuan Berbahasa Inggris Melalui Kegiatan Mendongeng Pada Siswa Sekolah Dasar Di Kota Tegal" pada 2 sekolah mitra yaitu SDIT Usamah dan SD Ihsaniyah Gajahmada yaitu:

\section{A. Perencanaan}

Kegiatan perencanaan berlangsung selama satu bulan. Kegiatan - kegiatan yang dilakukan pada tahap perencanaan adalah sebagai berikut.

1) Koordinasi antara Tim Pelaksana PKM dengan LPPM Universitas Pancasakti Tegal: Pelaksanaan kegiatan pada tahap ini dimulai dengan mengundang tim pelaksana untuk mengadakan pertemuan persiapan pelaksanaan dengan melibatkan LPPM Universitas Pancasakti Tegal, Tim pelaksana kemudian diberikan pembekalan mengenai maksud, tujuan, rancangan mekanisme Program Kemitraan Masyarakat (PKM), dan beberapa hal teknis berkaitan dengan metode/teknik pelaksanaan.

2) Sosialisasi Program Kemitraan Masyarakat (PKM) pada sekolah mitra (khalayak sasaran): Sosialisasi dilakukan dalam bentuk koordinasi antara tim pelaksana dengan sekolah mitra.

3) Penyusunan program pelatihan mendongeng menggunakan dongeng digital: Berdasarkan hasil identifikasi, hasil analisis permasalahan yang ada, hasil kebutuhan, dan hasil analisis potensi sekolah, selanjutnya disusun program pelatihan.

\section{B. Tindakan}

Tindakan dalam kegiatan ini berupa implementasi program, yang direncanakan berlangsung selama 2 bulan. Kegiatan-kegiatan yang dilakukan dalam implementasi program adalah sebagai berikut:

- Meningkatkan pengetahuan dan keterampilan para guru tentang pembuatan media pembelajaran dengan pendekatan IPTEK terapan. Kegiatan ini berupa sosialisasi ini dilakukan di dua sekolah mitra yaitu SDIT Usamah dan SD Ihsaniyah Gajahmada.

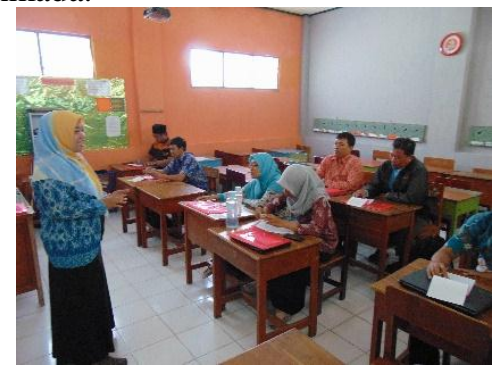

Gambar 1. Sosialisasi di SDIT dan SD Ihsaniyah.

- Mendemonstrasikan teknologi pembuatan media pembelajaran khususnya 3ahasa Inggris menggunakan teknologi digital.

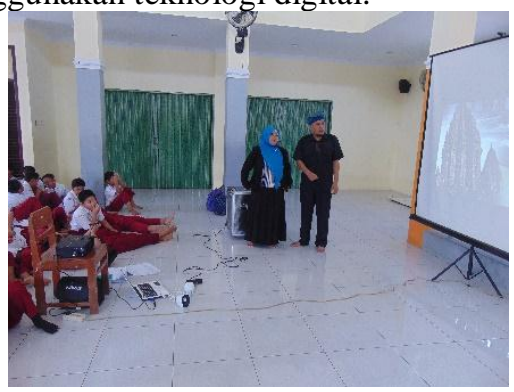

Gambar 2. Demonstrasi

- Pembimbingan dan praktek pembuatan media pembelajaran 120ahasa Inggris berbasis digital.

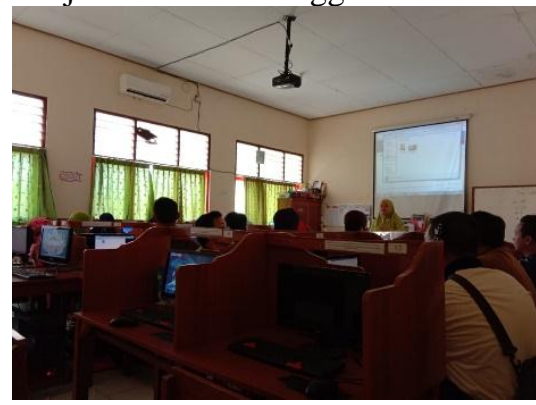

Gambar 3. Pembimbingan dan Pembuatan

- Pembimbingan cara penggunaan media pembelajaran berbasis dongeng digital dalam pembelajaran bahasa Inggris di kelas. Sebelum 
pelaksanaan pelatihan dilakukan koordinasi pelaksanaan dengan Kepala SDIT Usamah dan SD Ihsaniyah Gajahmada.

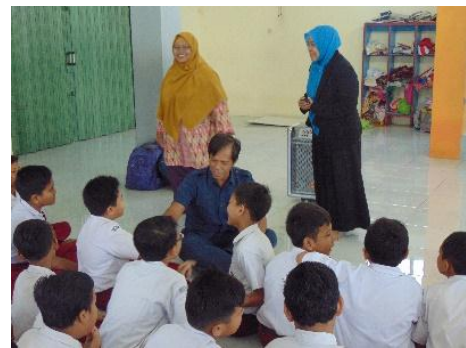

Gambar 4. Pembimbingan cara penggunaan media pembelajaran

- Memutar dongeng digital hasil karya pengusul pada siswa di Sekolah mitra yaitu SDIT Usamah dan SD Ihsaniyah Gajahmada.

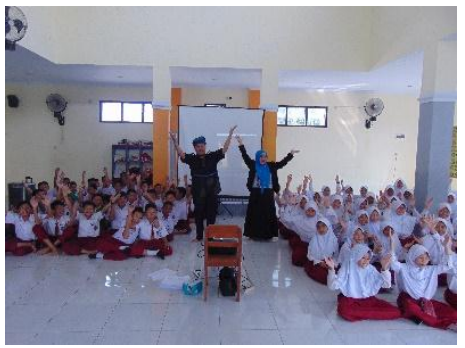

Gambar 5. Pemutaran dongeng digital

\section{Observasi dan Evaluasi}

Observasi dan evaluasi berlangsung dalam kurun waktu 3 bulan. Observasi dilakukan terhadap peningkatan kecerdasan emosi dan juga peningkatan kemampuan berbahasa Inggris siswa pada sekolah mitra. Instrument yang digunakan dalam tahap ini berupa angket yang diadopsi dari teori yang dicetuskan oleh Goleman (2004) tentang kecerdasan emosi (kuesioner terlampir). Untuk mengetahui kemampuan berbahasa Inggris siswa pada sekolah mitra, pengusul memberikan tes dasar tertulis bahasa Inggris. Pengusul memberikan pre-test dan posttest untuk mengetahui peningkatan kecerdasan emosi dan kemampuan berbahasa Inggris siswa pada sekolah mitra. Berdasarkan hasil evaluasi yaitu pemberian angket pada saat pre-test maupun post-test maka dapat disimpulkan bahwa terdapat kenaikan pada kecerdasan emosi sebesar $12 \%$ untuk SDIT Usamah dan 14\% untuk SD Ihsaniyah Gajahmada. Sedangkan kemampuan berbahasa inggris siswa mengalami peningkatan sebesar 9\% untuk SDIT Usamah dan $10 \%$ SD Ihsaniyah Gajahmada.

\section{Refleksi}

Kegiatan PKM pada akhirnya berjalan dengan sukses meskipun ditengah jalan menemui beberapa hambatan. Diantara hambatan tersebut adalah bahwa tidak mudah untuk memotivasu guru agar mau kreatif membuat media pembelajaran berbasis digital. Para guru lebih senang menggunakan media pembelajaran konvensional yaitu hanya spidol dan whiteboard, mereka enggan memanfaatkan teknologi karena memang belum tahu cara memanfaatkannya. Sehingga dalam pelaksanaan kegiatan tim pengabdi menggandeng guru TIK yang ada di sekolah mitra serta tim IT dari universitas untuk membantu para guru dalam membuat video pembelajaran.

\section{KESIMPULAN DAN SARAN}

Kegiatan PKM di SDIT Usamah dan SD Ihsaniyah Gajahmada meliputi perencanaan, tindakan, observasi dan evaluasi, serta refleksi. Kegiatan ini berjalan dengan baik dan lancar serta mendapat respon yang positif baik dari siswa maupun guru. Hal ini dapat dilihat dari antusiasme siswa maupun guru yang mengikuti rangkaian kegiatan dari awal hingga akhir. Para guru dari sekolah mitra sudah bisa mandiri menerapkan teknologi dengan membuat video pembelajaran berbasis digital. Kegiatan pembelajaran yang menggunakan dongeng digital telah mampu meningkatkan kecerdasan emosi dan kemampuan berbahasa Inggris siswa di sekolah mitra.

Saran yang dapat diberikan adalah Program kegiatan untuk meningkatkan kecerdasan emosi anak dan kemampuan berbahasa Inggris siswa Sekolah Dasar harus tetap berlanjut meskipun kegiatan PKM telah selesai dilaksanakan. Dosen yang berkecimpung dalam bidang psikologi anak harus tetap berkolaborasi dengan guruguru Sekolah Dasar demi tercapainya peningkatan kecerdasan anak tidak hanya emosi tapi juga moral, spiritual dan intelegensi. Dosen bahasa Inggris khususnya pengampu mata kuliah English for Young Learner harus terus aktif untuk melakukan penelitian terkait dengan peningkatan kemampuan berbahasa Inggris siswa Sekolah Dasar. Hasil penelitian para dosen ini sebaiknya disosialiasikan melalui kegiatan PKM. Laboratorium Universitas dapat dimanfaatkan oleh guru-guru untuk melakukan inovasi pada media pembelajaran khususnya yang berbasis teknologi.

\section{UCAPAN TERIMA KASIH}

Kami mengucapkan terima kasih kepada Direktorat Riset dan Pengabdian Kepada Masyarakat. Kementerian Riset, Teknologi, dan Pendidikan Tinggi yang telah mendanai kegiatan ini. 
Jurnal Pengabdian Masyarakat J-DINAMIKA, Vol. 3, No. 2, Desember 2018,

P-ISSN: 2503-1031, E-ISSN: 2503-1112

\section{DAFTARPUSTAKA}

[1] Goleman, D. (2005) Emotional Intelligence: Why it can matter more than $I Q$. New York: Bantam Books.

[2] Isbell, R. et al. (2004) 'The effects of storytelling and story reading on the oral language complexity and story comprehension of young children', Early Childhood Education Journal. doi: 10.1023/B:ECEJ.0000048967.94189.a3.

[3] Shapiro, L. E. (1998) How to Raise a Child with a High EQ: A Parents' Guide to Emotional Intelligence. New York: HarperPerennial.

[4] Staden, C. J. S. and Watson, R. (2007) 'When old is new: exploring the potential of using indigenous stories to construct learning in early childhood settings', in A paper presented at the AARE conference, Fremantle 26-29th November.

[5] Sulistianingsih, E. (2017) 'The effectiveness of learning model based digital storytelling to improve student's emotional intelligence', Jurnal Penelitian Pendidikan, 34(2), pp. 121-126. 